\title{
Facts, causes and corruption prevention: Evidence In Indonesian ministries
}

\author{
Anisa Dewi Arismaya \\ Magister Accounting, Satya Wacana Christian University, Salatiga, Indonesia \\ Intiyas Utami \\ Magister Accounting, Satya Wacana Christian University, Salatiga, Indonesia \\ intiyas@staff.uksw.edu
}

Follow this and additional works at: https://journal.uii.ac.id/jca

Copyright (C2019 Journal of Contemporary Accounting and Authors.

To cite this article: Anisa Dewi Arismaya \& Intiyas Utami (2019). Facts, causes and corruption prevention: Evidence In Indonesian ministries. Journal of Contemporary Accounting, 1(2), 95-106. doi:10.20885/jaca.vol1.iss2.art3 


\title{
Facts, causes and corruption prevention: Evidence in Indonesian ministries
}

\author{
Anisa Dewi Arismaya ${ }^{1}$, Intiyas $\mathrm{Utami}^{2}$ \\ ${ }^{1,2}$ Magister Accounting, Satya Wacana Christian University, Salatiga, Indonesia
}

\begin{abstract}
JEL Classification:
M40, D73

Keywords:

fraud, whistleblowing system, website of ministry
\end{abstract}

Corresponding Author:

intiyas@staff.uksw.edu

DOI:

10.20885/jca.vol1.iss2.art3

Copyright @ 2019

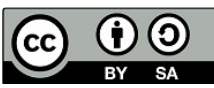

This is an open access under CC-BY-SA license

\begin{abstract}
This study aims to track corruption cases and describe the causes of corruption in the Indonesian ministry in 2016, 2017, 2018 using descriptive analysis. Data on corruption cases is taken from Indonesian online media news. Furthermore, identifying the level of implementation of the violation reporting system in the Indonesian ministry by using content analysis from the whistleblowing system website in 21 ministries in Indonesia using categorical items from the whistleblowing system implementation according to the KNKG 2008. The results of the study showed that 21 Indonesian ministries applied $19.84 \%$ of the reporting system which means it is in accordance with the reporting system criteria in accordance with the 2008 KNKG. This research will be input for the Indonesian ministry in implementing the reporting system and contribute in the field of accounting as a fraud prevention tool. This research update is carried out by conducting studies for each ministry in Indonesia that has a whistleblowing system website.
\end{abstract}

\section{Introduction}

The government management will be said to be good if it can maintain resources in public services and have anti-fraud governance arrangement. Vyas-Doorgapersad (2007) explains that there is a need for the public sector to adopt an integrity system as an analysis of the causes of corruption and anti-corruption in a country. Corruption is a fraud which is difficult to control and inevitable because it deals with personal interest and power (Bowman \& Gilligan, 2007). Bureaucratic factors also affect the temptation of corruption and can occur in all countries (Nguyen et al., 2017). Among countries in Southeast Asia, Indonesia has a high level of corruption. Data taken from the website (KPK, 2019), 287 of 781 cases of corruption in Indonesia were carried out by the ministry agencies and they were occurred in 2013, which were 46 cases. Although classified as quite high, corruption in the Indonesian government can actually be prevented by improving audit procedures and the information technology can be used to strengthen the investigation and to gain international transparency support (Tatiana, 2017). The whistleblowing system is one of tools to prevent fraud and support fraud reporting using information technology (Fieger \& Rice, 2018). Research of Nurhidayat and Kusumasari (2018) explains the condition of whistleblowing system in Indonesia that although a country has implemented a safe regulation and protection scheme for fraud reporters, it still needs a means of transparency for retaliation from the fraud perpetrator might happen (Fieger \& Rice, 2018). The KPK and the Witness and Victim Protection Agency (LPSK) collaborated in the implementation of whistleblowing system in the Indonesian ministries as one of efforts to uncover fraud. However, according to the National Committee on Governance Policy (2008) there has been no regulation issued officially by the government in the implementation of whistleblowing system in the Indonesian ministries in accordance with the whistleblowing system element in the KNKG 
module of 2008 .

Condition in Indonesia was revealed in study of Syamsuddin (2017) which show that the fraud reporters need support from their superiors, especially BPK (Financial Auditor Agency) and auditors because government auditors often provide unqualified opinions but the level of corruption was still high. The reporting in whistleblowing system may cause problems if its application is not done properly because it is necessary that the fraud reporters feel safe and are protected (Marwaha, 2017). There needs to be a review of the implementation of whistleblowing system in Indonesia because the rights of fraud reporters must be well considered that in turn it will improve the support of whistleblowing system as a means of anti-corruption protection in the government environment (Said et al., 2017).

Whistleblowing system is a disclosure unit that can be done via online, by fax, by letter or directly done and accompanied with or without disclosure of reporter's identity and with strong evidence (Semendawai et al., 2011). Gao and Brink (2017) explain that there are various factors influencing a whistleblowing system, including the characteristics of reporters, characteristics of demographic conditions such as age, gender and work experience, the characteristics of report recipients i.e. whether they can be trusted and reports handled appropriately, reporting channel characteristics, the characteristics of the perpetrators and the characteristics of an organization that can affect the organization in assessing violations.

The KPK has collaborated with the Indonesian ministries to create a corruption prevention system, namely the whistleblowing system. However, there are no official rules regarding the implementation of whistleblowing system along with the disclosure procedure used as a reference for the public sector in accordance with the KNKG 2008 module. 21 Indonesian ministries have implemented whistleblowing system in their websites. This research aims to explore corruption cases in Indonesian ministries in the last three years, i.e. 2016, 2017, and 2018 which were published in Indonesian online news mass media and describe the causes of corruption in Indonesian ministries. Next, this research will identify the application of whistleblowing system developed in the Indonesian ministries based on KNKG 2008.

This research is expected to be useful for the Indonesian ministries to be able to find out the shortcomings in the implementation of whistleblowing system in Indonesian ministries. Each ministries can compared to other ministries for implementation of whistleblowing system and help regulatory and policy authorities to strengthen anti-corruption mechanisms with a clear and easy-implemented procedure. The theoretical benefits of this research can be used as learning media to improve the comprehension and literature on whistleblowing system as a means of corruption prevention.

\section{Literature Study}

\section{Institutional Theory}

The institutional environment is a significant factor in influencing the culture of corruption along with external pressures such as the task environment, regulation, inconsistent structure, and institutional environment such as transparency, fairness, the complexity of institutions which can influence the level of corruption in the public sector (Sudibyo \& Jianfu, 2015). Lambsdorff (2007) explains that corruption in public sector has been a feature of institutions for centuries and in order to eradicate corruption, it requires a revised new strategy.

Choi (2018) reveals that a weak institution will be a challenge in corruption prevention and a weak institution can hamper a democratic progress and has a negative impact on the public. This is the reason about why controlling and preventing corruption is not an easy task. What can be done is to create accountability and cultural responsibility for institutions through awareness to disclose frauds (Hende, 2001). 


\section{Corruption}

Graycar and Sidebottom (2012) explains that corruption is a type of fraud which has patterns that can provide opportunities to commit other frauds due to social and technological changes. Corruption is a financial crime that has a severe loss impact. Things relating to corruption are ineffective law enforcement, lack of capital standards and codes of ethics, and institutional weakness (Dion, 2010). The act of corruption is an act that is contrary to someone's actual duties or rights (ACFE, 2019). Most of the employees in government agencies committed fraud because of financial pressure, opportunity to commit fraud and rationalization because they consider fraud as a common thing in their work environment (Abdullahi \& Mansor, 2018). Lack of transparency plays a role in fraud, so that corruption has been the most frequent committed frauds (Sobis, 2016).

ACFE (2019) describes various corruption schemes; the first is bribery scheme. Bribery schemes involve giving, receiving, asking for something, and offering so that this scheme involves business decisions. The next scheme is kickback scheme which is a scheme between vendors who make payments in secret to get favorable treatment. The next scheme is tender offer scheme that involves employees who commit fraud by helping vendors to win contracts through the bidding process. The next scheme is economic squeeze scheme that is carried out by employees or officials by using the power to demand money for certain business decisions. And the last scheme is illegal fraud scheme that involves receiving and giving something of value to certain business decisions.

\section{Corruption Prevention}

Prevention of corruption is important because corruption is a crime that leads to total future destruction that requires sustainable commitment in its implementation (Oyamada, 2015). Prabowo and Suhernita (2018) explains that in preventing corruption, it is necessary to adjust to the characteristics of a country such as Indonesia which needs to pay attention to cultural factors. One tool that can be used for anti-corruption effort is a web application for employees that can help prevent and detect corruption from an early stage, even though corruption is a crime that is difficult to eradicate. This can be done to prevent financial losses through the reporting mechanism.

Dasgupta and Kesharwani (2010) explain that employees are the best party to identify act of fraud in an organization. Organizations must encourage employees and protect them as whistleblowers. There are various ways that are disclosed to support whistleblowers, namely establishing complaint processes and investigating it quickly, training managers and employees, monitoring legislative actions, punishing fraud correctly, communicating policies, encouraging communication, developing codes of ethics, regulating complaint handling, and improving culture honesty and integrity in organizations.

Weak legislative frameworks can also create a complaint environment that is not conducive for complaints in a whistleblowing system. This was revealed in the research of Alleyne et al. (2017) which explained that even though a Whistleblowing System had been implemented, the absence of complaint laws and unclear regulations had reduced the confidence on internal reporting processes. The implementation of a whistleblowing system needs to prioritize adequate mechanisms for reporters, openness of management, independent committees in handling and encouraging anonymous reporting.

Meng and Fook (2011) also revealed that many countries in the world had good laws and governance in the public sector to support the implementation of a whistleblowing system. The same thing was expressed by Alleyne (2016) that individuals can be conservative and passive so that organizations need to support a whistleblowing system through a trusted and confidential 
mechanism. A whistleblowing system must be managed ethically towards public, employee manuals should be provided, it should have a written statement of mission and supporting work procedures.

\section{Whistleblowing System in Indonesia}

Semendawai et al. (2011) reveals that Indonesia has a law enforcement situation that is not strong enough so that any employers who are reported through a whistleblowing system can drag fraud reporter/informant into a guilty party. Indonesia needs to learn from other countries regarding the implementation of whistleblowing system applied in Australia, France, Britain, Canada and United States that have Whistleblower laws and especially in United States require disclosures about the achievement of management performance results; ethical codes; independence of audit committees; and adoption from the Good Corporate Governance rules that can be applied in the public sector.

The things that must be regulated in the whistleblowing system laws disclosed by Semendawai et al. (2011), namely disclosure procedures, follow-up steps for disclosure, anonymity and confidential reporting, and protection. The whistleblowing system is one of tools to prevent corruption and it requires protection schemes, strong communication channels, and management that supports transparency (Razak et al., 2015).

Indonesia needs to have an optimal and sustainable and transparent and multifunctional model of fraud prevention called Whistleblowing System (Kartini, 2018). Nurhidayat and Kusumasari (2018) explain that in developing of whistleblowing system in Indonesia needs to pay attention to aspects of legal protection for reporters; sufficient policies and ethics for whistleblowers to feel safe; easily accessed reporting channels for fraud reporters; and information that is used by management for verification of reporting which needs to be filtered and addressed to people who are authorized for follow-up processes. Syamsuddin (2017) explains that Indonesia needs support from employers and auditors regarding the implementation of whistleblowing system because it needs re-learning about the culture of corruption and replacing it gradually with knowledge about of the risk of corruption in the government.

\section{Corruption of the Indonesian Ministry}

Corruption in the Ministry of Indonesia already increasingly widespread and encroach on various elements that harm the country's finances and violate the social and economic rights of the community (BPHN, 2011). Corruption in Indonesia involves many public officials. Most of them are bribery cases with the reason that they get profit. Bribery occurs as a result of an imbalance in resources that can threaten democracy and weakening public institutions. Enforcement of bribery is a new stage and must be done effectively to create a deterrent effect for corruptors.

In addition to the bribery case, there are cases of buying and selling positions that make the KPK feel very sad and deplored the sale and purchase of positions at the ministry. Ministries should be able to provide good examples for other agencies. Moreover, open position selection is expected to close the corruption space and become a venue for selecting the ASN with the best competence for the right position (KPK, 2019).

\section{Research Method}

This study uses descriptive analysis by describing the forms of corruption cases in the Indonesian ministry and describing the causes of corruption cases in the Indonesian ministry. This research reveals the forms of corruption that occurred and was published in the online media news in the Indonesian ministry for three years, namely 2016, 2017, and 2018. The criteria for data collection in the Indonesian online media news are looking for forms of corruption cases that occurred in the Indonesian ministry the data includes forms of corruption and related information such as the 
name of the ministry, the name of the suspect, other parties involved in the corruption case, and the cause of the corruption case can be revealed. This analysis is also used to analyze the causes of corruption cases that often occur and explain the importance of corruption prevention models in the form of whistleblowing systems applied in the ministry of a country.

Data collection was done separately by giving a score of 1 for the appropriate application and 0 because there was no corresponding application for the category of whistleblowing system. Information from the website was downloaded and printed between 6 May 2019 to 18 May 2019. After scoring the application of the whistleblowing system based on the 2008 KNKG.

\section{Results and Discussion}

\section{Corruption of the Indonesian Ministry}

Indonesia has corruption cases every year and the data obtained from this study comes from data on Indonesian online news media in 2016, 2017, and 2018. The first case was disclosed on the online news of CNN Indonesia (2016) which revealed that the KPK had determined the bribery case suspects on the project of ministry of public works and public housing (PUPR). This was the corruption case of bribery of 2016 budget project by the director of PT Sharleen Raya, John Alfred, to members of the house of representatives commission $\mathrm{V}$ to propose a development project in Maluku as an aspiration program and forwarded to the ministry of PUPR.

The corruption case in 2017 was also a bribery case reported by an online news portal CNN Indonesia (2018) involving officials from the ministry of public works and public housing related to the project to develop a drinking water supply system for the 2017/2018 budget. The suspects among others were the director of PT WKE, director of OT TSP, officers of Lampung SPAM commitment making, head of SPAM work unit.

Sindonews.com (2018) published online news on corruption cases in 2018 namely bribery cases involving the director general of the ministry of transportation and his expert staffs in logistics, multimodal, and transportation safety by accepting bribes from PT Adghiguna Kaeruktarama related to dredging project of shipping lines of Pulang Pisau port in Central Kalimantan and Samarinda port in East Kalimantan as well as approval for dredging work permit for PT Indominco Mandiri, PT Indonesia power unit service PLTU Banten, and port authority office in Semarang.

Three online media also revealed corruption cases that occurred in the Indonesian ministries. All disclosed cases were bribery cases that involved someone's authority to make certain business decisions and getting benefit from the decision. Corruption in Indonesian ministries shows that certain officials in Indonesia who have authority over government projects use the authority to take advantage of it.

Corruption in the Indonesian ministries that were revealed by news media, several of those cases involved regional officials who were not reported online. Prabowo and Cooper (2016) revealed that corruption is difficult to eradicate in Indonesia because its weak democracy and lack of transparency to the public so that examination of acts of corruption becomes ineffective because of behavioral and cultural factors. Behavior and culture of corruption are considered as normal in the Indonesian ministries. The system for procuring projects that uses tender is often rigged with bribery so that those projects can be obtained by the private sector in an easy way. This includes one of frauds in the process of procuring goods and services. Corruption in procurement is easy to commit because the implicated ministries have the authority to choose and determine with whom the transaction will be carried out.

Corruption in the procurement of goods and services is an act against the law by enriching oneself which can be detrimental to the Indonesian economy and difficult to eradicate. Transparency International (2012) revealed that there are various factors that made it difficult for Indonesia to tackle corruption. The first factor is the structural factor in the form of income. 
The second factor is the historical factor because since the Suharto regime era, the culture of corruption has a strong root. The third factor is decentralization which local government should be responsible for the use of public money, not the other way around.

\section{Implementation of the Whistleblowing System as a Corruption Prevention Tool}

The whistleblowing of whistleblowing system application on websites of 21 Indonesian ministries is based on 6 aspects and the results are presented in table 2 and table 3. Indonesia has 30 ministries and only 21 ministries that have whistleblowing system whose data can be accessed. The results of 36 items in the disclosure category, 21 ministries $(19.84 \%)$ have implemented the whistleblowing system in accordance with the KNKG 2008 criteria. The results of the study show that there are 6 items from 36 categories that almost all Indonesian ministries have applied according to the criteria. Those items are the implementation launching of whistleblowing system; the implementation of a fully whistleblowing system that is ready to receive reports and processes; a policy that guarantees whistleblowers for their confidentiality and security; preparation of procedures for reporting of frauds which includes anonymous reports; final check-up of all whistleblowing system infrastructures including existing helplines, and protection policy for reporters authorized by the board of directors and board of commissioners.

There are 6 categories of items that are not applied by any ministries in Indonesia, namely the provision of sanctions on false and slanderous reports; the provision of the reporter's rights if it results an improper treatment from the reporting, the reporter can appeal to law enforcement; the launching preparation of the whistleblowing system program which include: Signing of commitment of the board of directors and the board of commissioners and senior corporate officers, remarks from the board of directors/board of commissioners, remarks from outside of the company, introduction to the whistleblowing system and phone number to be contacted, determination of the launching ceremony of whistleblowing system implementation and physical preparation and other events, composing of schedule for review and monitoring, and performance of the whistleblowing system program review/assessment.

Criteria for completeness of the whistleblowing system menu the ministry has aspects of the home, complaint menu, flow and statement of the management of the whistleblowing system, dashboard, and complaints. The home menu contains page titles and logs in, the complaint menu contains the complaints procedure, online registration procedures to get a username, legal basis, managing a whistleblowing system, office address, telephone/fax, and location map. In the flow menu and statement of the management of the whistleblowing system contains the flow of the process of receiving reports to follow-up reports and information on services. The dashboard menu contains a complaint report and a graph of the number of complaints. Complaints menu contains a list of complaints containing a list of complaints, information on complaints, profile of the reporter, change passwords, and logout.

Most of the contents of the whistleblowing system menu at the Indonesian ministry have a complete set on the home menu and complaints. The Indonesian ministry's home menu contains a page title that can contain an explanation of the whistleblowing system that the Indonesian ministry has implemented and $\log$ in for the whistleblower to register or enter the website in order to do the reporting. Because most of the whistleblowing system in the Indonesian ministry requires the whistleblower to register. In the complaint menu, whistleblowers access reporting and check reporting. In this complaint menu, most of the whistleblowing system of the Indonesian ministry requires the whistleblower to fill in the complete data including name, gender, occupation, identity number, address, and type of identity.

The results show that the implementation of the whistleblowing system has not been said to be optimal even though it is important for whistleblowers to have legal power with effective complaints. This also encourages whistleblowing at an early stage through structured procedures (Yeoh, 2014). A strong reason to support the implementation of a whistleblowing system is that an 
employee will not make any disclosures until he is heard and there is a need to use a whistleblowing system. The whistleblowing system is important for the survival of an organization and provides more economic benefits than costs.

The under optimal whistleblowing system occurs due to the absence of specific rules regarding the implementation of whistleblowing system in Indonesian ministries, as a result, those ministries that have whistleblowing system implement the system according to the needs of each ministry. Moreover, there are several ministries that have whistleblowing system with content that are not easily understood, reporting flow that is not explained properly, and system that does not have a helpdesk for the whistleblowing system, an as a result, the public cannot trust the system and they are reluctant to report any frauds. LPSK and KPK have collaborated to protect whistleblowers. However, this would be futile if the ministries in Indonesia do not support the whistleblowing system as a means of preventing of corruption. The Indonesian ministries only have websites as prerequisite of anti-corruption tool but they do not fully implement the program principles. There are many elements of program implementation that are not implemented properly so that the whistleblowing system in ministries still has to be improved continuously.

The first element in whistleblowing system program improvement for Indonesian ministries is to appoint employees as the team of whistleblowing system accompanied by job descriptions, administrative processes, and an independent investigation process. Second element is complaint procedures, easily accessible complaint channels, protection policy for reporters and anonymous reporting. Third element is training and socialization programs for employees in implementing whistleblowing system in work environment. Fourth element is the availability of helplines and reviews so that program improvements that can be carried out on an ongoing basis.

It is important for an institution to support a new culture with the aim of continuous improvement, which is to prevent existing corruption. Factors that can affect the institutional environment in the Indonesian ministry in supporting the implementation of the whistleblowing system are transparency. Transparency requires the disclosure of information to the public from an institution that can suppress corrupt practices replaced by a new culture of information disclosure that supports institutions in promoting an anti-corruption culture. The institutional environment needs to change existing structures and practices that still allow superiors and employees to take a gap to commit corruption fraud.

The application of the whistleblowing system in the Indonesian ministry can change the structure and work practices of an institution. Institutions can implement the whistleblowing system in accordance with the prevailing organizational culture so that employees are easy to accept and in accordance with the social environment at the institution. This change focuses on the responsibility of every employee to become a whistleblower if knowledge of fraud occurs, adherence to existing rules so as to create an adequate climate of internal control, changes in norms of corrupt behavior replaced with behavioral awareness of an anti-corruption culture, and effective law enforcement in the agency. Changes to the structure and practice of institutions are indeed things that must be done in stages by building new values and the need for trust for employees who serve as whistleblowers for the institutions where they work.

The development of the trust of employees who serve as whistleblowers can be done by the institution by conducting socialization and training, strengthening the law and protection of reporters and implementing a improvement whistleblowing system in a gradual manner. Institutions can conduct outreach and training to employees by building awareness of disclosure of fraud they know without fear of retaliation for reporting. Socialization and training can be carried out in stages and adjusted to the working climate of each institution so that employees can receive the delivery of material easily and do not feel pressured over the new culture created.

The application of the whistleblowing system must also use ethical and supportive procedures as proof that the institution not only implements a corruption prevention model as symbolic, but also wants to transform the institution into an institution that supports anti- 
corruption. An institution requires strong rules on the follow-up to incoming fraud reports, follow-up by an independent party, and if proven to be brought to justice with appropriate sanctions. This procedure is important to be applied in every institution so that the reporter believes that the whistleblowing system is not just a corruption complaint tool, but can help prevent corruption from happening because employees know what risks they can get if they commit corruption fraud.

The application of a whistleblowing system that is tailored to the social environment of an institution can help employees adapt easily. In addition, this makes the public's trust in the institution as an anti-corruption institution because external factors also influence the existence of the implementation of the whistleblowing system. Institutions that involve external factors, namely the public community can feel helped because the public will help supervise the performance of employees at the institution. The whistleblowing system that is created should not only involve employees as reporters but the public can also make complaints with strong criteria and evidence.

Tables 1. Disclosure on the Website Whistleblowing system The Indonesian Ministry's based on the $2008 \mathrm{KNKG}$

\begin{tabular}{llcc}
\hline No. & \multicolumn{1}{c}{ Ministries of Indonesia } & $\begin{array}{c}\text { Total disclosure of } \\
\text { Whistleblowing based } \\
\text { on KNKG 2008 }\end{array}$ & Percentage \\
\hline 1 & Ministry of Religion & 13 & 36.11 \\
2 & Ministry of Education and Culture & 12 & 33.33 \\
3 & Ministry of Administrative and Bureaucratic Reform & 12 & 33.33 \\
4 & Ministry of Women Empowerment and Child Protection & 12 & 33.33 \\
5 & Ministry of Public Works and Public Housing & 11 & 30.56 \\
6 & Ministry of Law and Human Rights & 8 & 22.22 \\
7 & Ministry of Youth and Sports & 8 & 22.22 \\
8 & Ministry of Transportation & 7 & 19.44 \\
9 & Ministry of Energy and Mineral Resources & 7 & 19.44 \\
10 & Ministry of Maritime Affairs and Fisheries & 7 & 19.44 \\
11 & Ministry of Village, Development of Underdeveloped & 7 & 19.44 \\
& Region and Transmigration & & \\
12 & Ministry of Agriculture & 6 & 16.67 \\
13 & Ministry of Agrarian and Spatial Planning & 6 & 16.67 \\
14 & Police of Republic of Indonesia & 6 & 16.67 \\
15 & Ministry of State-owned Enterprises & 6 & 16.67 \\
16 & Ministry of Finance & 5 & 13.89 \\
17 & Coordinator Ministry of Economy & 5 & 13.89 \\
18 & Ministry of Trade & 4 & 11.11 \\
19 & Ministry of Social & 3 & 8.33 \\
20 & Ministry of Industry & 3 & 8.33 \\
21 & Ministry of Health & 2 & 5.56 \\
\hline & Total & 150 & 19.84 \\
\hline
\end{tabular}

It is hoped that the comparative whistleblowing system of the Indonesian ministry with other countries will be carried out by subsequent researchers to increase knowledge regarding the application of an effective whistleblowing system, especially in countries that have already implemented a whistleblowing system. In addition, further research can be carried out using more detailed meta-analysis methods regarding the contents of the whistleblowing system website in each Indonesian ministry and tracing corruption cases that exist in each Indonesian ministry every year. Investigation of corruption cases in each of the Indonesian ministries can be related to the implementation of the whistleblowing system to find out whether there is a 
decrease in corruption after the implementation of the whistleblowing system in the Indonesian ministry. Indonesian ministries should have regulations and policies regarding the content of the whistleblowing system and its contents so that each ministry has a website with a complete menu so as to facilitate the reporter and increase the confidence of whistleblower.

Tables 2. Implementation of Whistleblowing System Program Checklist

\begin{tabular}{ll}
\hline I & Early Preparation Stage \\
\hline 1. & The appointment of a team to establish and implement a whistleblowing system while preparing \\
it in accordance with the agreement of the Directors and Commissioners. \\
2. & Each executive of whistleblowing system unit is composed with clear job descriptions. \\
3. Selection of candidate employees who handle reporting in the whistleblowing system. \\
4. Determining of employees who are responsible for the processes of investigation, reporting \\
5. Training and comparative studies for whistleblowing system. \\
\hline II $\quad$ Continued Preparation Stage \\
\hline 6. & Reporting media for whistleblowers that can be accessed using hotlines, emails or special postal \\
7. & Leges and procurement of office physical facilities. \\
8. & Composing of procedures for submitting of fraud/violation reports, including anonymous \\
9. $\quad$ Guidelines for procedures for reporters concerning behaviors that can be reported as violations \\
and about explanation of the level of violations. \\
10. Provisions for sanctions for false and slanderous reports. \\
11. Policy on guarantees for reporters concerning confidentiality and security. \\
12. Protection policy for reporters authorized by the Board of Directors and Board of \\
13. Commissioners.
\end{tabular}

14. Statement of commitment to the implementation of whistleblowing system which it is the responsibility of all employees and the system is signed by the Board of Directors, Board of Commissioners and all employees.

15. Effective and fast delivery of material for Executive Briefings for Board of Directors and Board of Commissioners.

16. Workshop material for Management and Training for managers who will provide training.

17. Material for Whistleblowing System socialization that is carried out equally to all employees.

18. Briefing for Directors and Commissioners.

III Launching Of Whistleblowing System Program

19. Preparation of promotional material and duplication of the manual for information on whistleblowing system to be shared with employees and guests.

20. The launching preparation of Whistleblowing System program, which includes: Signing the commitment of the Board of Directors, Board of Commissioners and Senior Officials of Company; Remarks from the Board of Directors/Board of Commissioners; Remarks from outside the company; Introduction of the executive officer of Whistleblowing System and the phone number of contact parties.

20. The timing of the launch ceremony for the implementation of Whistleblowing System and physical preparation and other events.

22. Implementation of the Whistleblowing System Implementation Launching.

20. Continuing promotional activities and Soft Launching of Whistleblowing System.

IV Training Dan Socialization

24. Compilation of company-wide training schedules and overall socialization.

25. Logistics and accommodation preparation for training and outreach.

26. Socialization/workshop for Senior Managers.

27. Socialization and workshop for Managers.

28. Training for Trainers for Managers 
29. Training and socialization for employees.

\begin{tabular}{ll}
\hline $\mathrm{V}$ & Implementation of Whistleblowing System \\
\hline 30. & Final checkup of all Whistleblowing System infrastructures which includes the existing Helplines. \\
31. & Full implementation of the Whistleblowing System and readiness to accept reporting and its \\
& processes. \\
32. & Planning of periodic communication activities. \\
33. & Implementation of periodic communication. \\
\hline VI & MONITORING \& REVIEW \\
\hline 34. & Compilation of monitoring and review schedules. \\
35. & Implementation of the Whistleblowing System program review/assessment. \\
36. & Implementation of recommendations for improvement of assessment results.
\end{tabular}

Source: National Committee of Governance Policy (2008)

\section{Conclusion}

Corruption cases in the Indonesian ministry published in the Indonesian online news media in 2016, 2017 and 2018 are in the form of bribery cases that constitute financial crimes that often occur in the Indonesian ministry. This could be due to bureaucratic factors and lack of transparency in the public sector. Officials from the Indonesian ministry can take advantage of regional projects because they have decision making authority over budgeting and project implementation so that they are often used as a means of corruption. Bribery behavior in the ministry is a culture that has taken root for many years and is difficult to eradicate so that the Indonesian ministry needs a model of corruption prevention that can detect and reduce corruption, namely the whistleblowing system. The identification of the implementation of the whistleblowing system within the Indonesian ministry which was carried out in 21 Indonesian ministries referring to the $2008 \mathrm{KNKG}$ module showed that $19.84 \%$ of the Indonesian ministries had implemented a whistleblowing system in accordance with the $2008 \mathrm{KNKG}$ module.

\section{Acknowledgment}

The researcher greatest appreciation also goes to Mrs. Intiyas Utami as my examiner and also the head of Magister Accounting for his advice, supervision, and crucial contribution in the improvement of the result of this undergraduate thesis.

\section{References}

Abdullahi, R., \& Mansor, N. (2018). Fraud prevention initiatives in the Nigerian public sector: Understanding the relationship of fraud incidences and the elements of fraud triangle theory. Journal of Financial Crime, 25(2), 527-544.

ACFE. (2019). Introduction to Bribery and Corruption. Association of Certified Fraud Examiners. https://www.acfe.com/selfstudy.aspx?zid=2c92a0fe6a07e3e5016a27279b734057

Alleyne, P. (2016). The influence of organisational commitment and corporate ethical values on non-public accountants' whistle-blowing intentions in Barbados. Journal of Applied Accounting Research, 17(2), 190-210.

Alleyne, P., Charles-Soverall, W., Broome, T., \& Pierce, A. (2017). Perceptions, predictors and consequences of whistleblowing among accounting employees in Barbados. Meditari Accountancy Research, 25(2), 241-267.

Bowman, D., \& Gilligan, G. (2007). Public awareness of corruption in Australia. Journal of Financial Crime, 14(4), 438-452.

BPHN. (2011). Laporan Akhir Tim Kompendium Hukum Tentang Lembaga Pemberantasan Korupsi. 
https://www.bphn.go.id/data/documents/kpd-2011-7.pdf

Choi, J.-W. (2018). Corruption control and prevention in the Korean government: Achievements and challenges from an institutional perspective. Asian Education and Development Studies, 7(3), 303-314.

CNN Indonesia. (2016, December 17). KPK Tetapkan Tersangka Baru Suap Proyek Kementerian PUPR. CNN Indonesia. https://www.cnnindonesia.com/nasional/20161207172333-12-178022/kpk-tetapkantersangka-baru-suap-proyek-kementerian-pupr

CNN Indonesia. (2018, December 30). KPK Tetapkan Delapan Tersangka Kasus Korupsi Proyek Air Minum. Indonesia. https://www.cnnindonesia.com/nasional/20181229235642-12-357307/kpk-tetapkandelapan-tersangka-kasus-korupsi-proyek-air-minum

Dasgupta, S., \& Kesharwani, A. (2010). Whistleblowing: A survey of literature. The IUP Journal of Corporate Governance, 9(4), 57-70.

Dion, M. (2010). What is corruption corrupting? A philosophical viewpoint. Journal of Money Laundering Control, 13(1), 45-54.

Fieger, P., \& Rice, B. S. (2018). Whistle-blowing in the Australian Public Service: The role of employee ethnicity and occupational affiliation. Personnel Review, 47(3), 613-629.

Gao, L., \& Brink, A. G. (2017). Whistleblowing studies in accounting research: A review of experimental studies on the determinants of whistleblowing. Journal of Accounting Literature, 38, 1-13.

Graycar, A., \& Sidebottom, A. (2012). Corruption and control: a corruption reduction approach. Journal of Financial Crime, 19(4), $384-399$.

Hende, R. van den. (2001). Public Concern at Work: supporting public-interest whistleblowing. The Journal of Adult Protection, 3(3), 41-44.

Kartini. (2018). eveloping fraud prevention model in regional public hospital in West Sulawesi Province. International Journal of Law and Management, 60(2), 210-220.

KNKG. (2008). Pedoman Umum Good Public Governance.

KPK. (2019). Graph TPK Berdasarkan Instansi. Komisi Pemberantasan Korupsi. https://www.kpk.go.id/id/statistik/penindakan/tpk-berdasarkan-instansi

Lambsdorff, J. G. (2007). The Institutional Economics of Corruption and Reform: Theory, Evidence and Policy (1st ed.). Cambridge University Press.

Marwaha, K. (2017). Corporate governance and whistle blowing in India: promises or reality? International Journal of Law and Management, 59(3), 430-441.

Meng, T. P., \& Fook, O. S. (2011). Comparative analysis of whistleblower protection legislations in England, USA and Malaysia. African Journal of Business Management, 5(2), 11246-11255.

Nguyen, T. V., Bach, T. N., Le, T. Q., \& Le, C. Q. (2017). Local governance, corruption, and public service quality: Evidence from a national survey in Vietnam. International Journal of Public Sector Management, 30(2), 137-153.

Nurhidayat, I., \& Kusumasari, B. (2018). Strengthening the effectiveness of whistleblowing system: A study for the implementation of anti-corruption policy in Indonesia. Journal of Financial Crime, 25(1), 140-154. 
Oyamada, E. (2015). Anti-corruption measures the Japanese way: prevention matters. Asian Education and Development Studies, 4(1), 24-50.

Prabowo, H. Y., \& Cooper, K. (2016). Re-understanding corruption in the Indonesian public sector through three behavioral lenses. Journal of Financial Crime, 23(4), 1028-1062.

Prabowo, H. Y., \& Suhernita. (2018). Be like water: Developing a fluid corruption prevention strategy. Journal of Financial Crime, 25(4), 997-1023.

Razak, S. N. A. A., Noor, W. N. B. W. M., \& Zakaria, M. (2015). Breaking the silence: The efficacy of whistleblowing in improving transparency. Scientific Research Journal, 3(4), 35-39.

Said, J., Alam, M. M., Mohamed, D. I. B., \& Rafidi, M. (2017). Does job satisfaction, fair treatment, and cooperativeness influence the whistleblowing practice in Malaysian Government linked companies? Asia-Pacific Journal of Business Administration, 9(3), 220-231.

Semendawai, A. H., Wiryawan, S. M., Wagiman, W., Susilaningtyas, Omas, B. I., Santoso, F., Sulistiani, L., \& Widiyanto. (2011). Memahami Whistleblower. Lembaga Perlindungan Saksi dan Korban (LPSK).

SINDONEWS.com. (2018, May 15). Kasus Suap Pelabuhan Kemenhub, Tonny Divonis 5 Tahun Bui. SINDONEWS. https://nasional.sindonews.com/read/1306737/13/kasus-suappelabuhan-kemenhub-tonny-divonis-5-tahun-bui-1526564560

Sobis, M. D. V. I. (2016). Increasing transparency is not always the panacea: An overview of alternative paths to curb corruption in the public sector. International Journal of Public Sector Management, 29(3), 255-270.

Sudibyo, Y. A., \& Jianfu, S. (2015). Institutional theory for explaining corruption: An empirical study on public sector organizations in China and Indonesia. Corporate Ownership \& Control, 13(1), 817-823.

Syamsuddin. (2017). The government whistleblowers in generating audit quality (a survey on provincial audit boards in South, Central, and West Sulawesi, Indonesia). International Journal of Law and Management, 59(6), 1046-1058.

Tatiana, A. (2017). Fraud prevention by government auditors. 12th Iberian Conference on Information Systems and Technologies (CISTI), 1-6. https://doi.org/10.23919/CISTI.2017.7976024

Transparency International. (2012). Causes of Corruption in Indonesia. Transparency International. https://www.transparency.org/whatwedo/answer/causes_of_corruption_in_indonesia

Vyas-Doorgapersad, S. (2007). Corruption in the Public Sector: A comparative analysis. Journal of Public Administration, 42(5), 285-299.

Yeoh, P. (2014). Enhancing effectiveness of anti-money laundering laws through whistleblowing. Journal of Money Laundering Control, 17(3), 327-342. 